\title{
TIÊN LƯợNG RỐI LOẠN NHỊP TIM NGUY HIỂM SAU PHẪU THUẬT TỨ CHÚNG FALLOT BẦNG KẾT HỢP ĐIỆN THẾ MUỘN VÀ BIẾN THIÊN NH!̣P TIM
}

\author{
Hoàng Anh Tiến*, Đoàn Chí Thắng*
}

\section{TÓM TẮT}

74 bệnh nhân> 15 tuổi mắc tứ chứng Fallot đã được phẫu thuật sửa chữa hoàn toàn và theo dõi rối loạn nhịp tim nguy hiểm trong vòng 3 năm. Bệnh nhân được đo Holter 24 giờ và điện thế muộn, dùng đường cong ROC đánh giá độ nhạy và độ đặc hiệu của điện thế muộn và biến thiên nhịp tim trong tiên lượng rối loạn nhịp nguy hiểm. Dùng OR so sánh giá trị kết hợp biến thiên nhịp tim và điện thế muộn. Điểm cắt tốt nhất của HFQRSd trong tiên lượng rối loạn nhịp thất là lớn hơn $151 \mathrm{~ms} ; \mathrm{AUC}=0,783$; Độ nhạy: 86,4\%; Độ đặc hiệu: 63,5\%. Điểm cắt tốt nhất của HFLA trong tiên lượng rối loạn nhịp thất là lớn hơn 47ms; $A U C=0,654$; Độ nhạy: 50\%; Độ đặc hiệu: $88,5 \%$. Điểm cắt tốt nhất của RMS trong tiên lượng rối loạn nhịp thất là nhỏ hơn hoặc bằng $21 \mu \mathrm{V}$; $\mathrm{AUC}=$ 0,633; Độ nhạy: 59,1\%; Độ đặc hiệu: 71,2 \%.Bệnh nhân có $\mathrm{DTM}(+)$ và giảm $\mathrm{BTNT}$ thì dự báo khả năng rối loạn nhịp tim cao gấp 13,14 lần $(\mathrm{OR}=13,14)$ so với nhóm bệnh nhân có ĐTM (-) và BTNT không giảm, với $\mathrm{p}<0,05$.

Kết hợp điện thế muộn và biến thiên nhịp tim cho giá trị cao nhất dự báo rối loạn nhịp tim nguy hiểm.

\section{SUMMARY}

74 Tetralogy of Fallot patients> 15 years of age were completely surgeryrepair and tracking dangerous arrhythmia within 3 years. The patient was measured 24-hour Holter ECGand signal-averaged electrocardiography; using ROC curves assess the sensitivity and specificity in prognosis dangerous arrhythmias. Use the OR to compare the combination value of heart rate variability and signal-averaged electrocardiography. The best cut-offpoint of HFQRSdprognosis in ventricular arrhythmias is greater than $151 \mathrm{~ms}$; AUC = 0.783; Sensitivity: 86.4\%; Specificity: $63.5 \%$. The best cut-offpoint of HFLA prognosis in ventricular arrhythmias is greater than 47 ms; $\mathrm{AUC}=0.654$; Sensitivity: 50\%; Specificity: $88.5 \%$. The best cut-offpoint of RMS in ventricular arrhythmias prognosis is less than or equal $21 \mu \mathrm{V}$; AUC $=0.633$; Sensitivity: $59.1 \%$; Specificity: $71.2 \%$.
Patients with signal-averaged electrocardiography(+) and decrease the heart rate variability can predict dangerous ventricular arrhythmias 13.14 times higher $(\mathrm{OR}=13.14)$ compared with patients with signalaveraged electrocardiography(-) and heart rate variabilitypersist, with $\mathrm{p}<0.05$.

Combined signal-averaged electrocardiographyand heart rate variability have the best power for predictingthe dangerous arrhythmias.

\section{I. ĐẠTT VẤN ĐỀ}

Tứ chứng Fallot là một trong những bệnh tim bẩm sinh có tím phổ biến, chiếm tỷ lệ 1/3500 trẻ em mới sinh, $7-10 \%$ các bệnh lý tim bẩm sinh. Theo nghiên cứu của tác giả Villafane $\mathrm{J}$ và cộng sự (2013), cho thấy tỷ lệ rối loạn nhịp thất nguy hiểm chiếm tỷ lệ $10 \%$ và tỷ lệ đột tử chiếm tỷ lệ khoảng $0,2 \%$ ở bệnh nhân tứ chứng Fallot sau phẫu thuật sửa chữa hoàn toàn và nguyên nhân chính gây đột tử chính là cơn nhịp nhanh thất bền bĩ [17]. Theo khuyến cáo của $\mathrm{ACC} / \mathrm{AHA}(2008)$ và Hội tim mạch học Việt Nam (2010), các bệnh nhân tứ chứng Fallot sau phẫu thuật sửa chữa hoàn toàn nên được theo dõi hằng năm với khám lâm sàng, điện tim, đánh giá chức năng thất phải, biến thiên nhịp tim và Holter điện tim định kỳ [2],[19].

Điện tim trung bình tín hiệulà mộtphương phápgiúp íchđể xác địnhbệnh nhân cócơnnhịp nhanh thấtkhông bền bĩ và hữu ích trong việc dự đoánloạn nhịp thấtnghiêm trọng hơn vàđột tử [9]. Ngoài ra, các chỉ số biến thiên nhịp tim (BTNT) được đánh giá bằng Holter điện tim 24 giờ sẽ phản ánh hoạt động của thần kinh tự động tim và là những thông số dự báo đối với các rối loạn nhịp thất nguy hiểm.

Xu hướng y học hiện nay là kết hợp hai hoặc nhiều phương pháp để vừa phát huy mặt mạnh của mỗi phương pháp vừa khắc phục nhược điểm của mỗi

\footnotetext{
* Bệnh viện Trung urơng Hué

Người chịu trách nhiệm khoa học: PGS.TS. Hoàng Anh Tiến

Ngày nhận bài: 18/06/2016 - Ngày Cho Phép Đăng: 18/08/2016

Phản Biện Khoa học: PGS.TS. Đặng Ngọc Hùng
} GS.TS. Bùi Đức Phú 
phương pháp. Do đó phối hợp điện thế muộn, biến thiên nhịp tim/Holter điện tim 24 giờ nhằm phát hiện và dự báo rối loạn nhịp tim nguy hiểm ở bệnh nhân tứ chứng Fallot đã phẫu thuật là một hướng đi mới và là giải pháp tốt trong dự báo rối loạn nhịp tim đặc biệt là rối loạn nhịp thất nguy hiểm với các mục tiêu:

1/ Đánh giá các rối loạn nhịp tim nguy hiểm bằng điện thế muộn, biến thiên nhịp tim sau phẫu thuật sửa chữa hoàn toàn tứ chứng Fallot.

2/ Kết hợp biến điện thế muộn và biến thiên nhịp tim để dự báo rối loạn nhịp tim nguy hiểm sau phẫu thuật sửa chữa hoàn toàn tứ chứng Fallot.

\section{II. ĐỐI TƯợNG VÀ PHƯơng PHÁP NGHIÊN CÚU}

\section{1. Đối tượng nghiên cứu}

74 bệnh nhân đã được chẩn đoán và phẫu thuật sửa chữa hoàn toàn tứ chứng Fallot, được theo dõi tại khoa chẩn đoán và thăm dò chức năng tim mạch Bệnh viện trung ương Huế và Bệnh viện trường Đại học $\mathrm{Y}$ Dược Huế, từ tháng 08 năm 2011 đến tháng 04 năm 2014.

\subsubsection{Tiêu chuẩn chọn bệnh nhân nghiên cứu}

Tất cả bệnh nhân từ 15 tuổi trở lên, đã được chẩn đoán và phẫu thuật sửa chữa hoàn toàn tứ chứng Fallot. Các bệnh nhân có chỉ định và thực hiện hoàn chỉnh các phương pháp thăm dò điện tim không xâm nhập.Các bệnh nhân đều được giải thích và tự nguyện đồng ý tham gia nghiên cứu.

\subsubsection{Tiêu chuẩn loại trừ}

Những bệnh nhân đã phẫu thuật sửa chữa hoàn toàn tứ chứng Fallot có các bệnh lý phối hợp như sau:

- Bệnh nhân suy thận, đái tháo đường, rối loạn điện giải đồ.

- Bệnh nhân đang nhiễm trùng nặng, bệnh lý phổi mạn tính.

- Bệnh nhân có các bệnh lý van tim phối hợp khác như hẹp hở van 2 lá, hẹp hở van động mạch chủ.

- Bệnh nhân đang đặt máy tạo nhịp hay ICD, bệnh nhân rung nhĩ mãn tính, bệnh nhân đang điều trị các thuốc có ảnh hưởng đến nhịp tim.

\subsection{Phương pháp nghiên cứu} 3 năm

\subsection{Phương tiện nghiên cứu}

\subsection{1 Điện thế muộn}

Điện thế muộn được ghi trên máy MAC 5500, sản xuất năm 2008 của hãng GE HEALTHCARE - MỸ

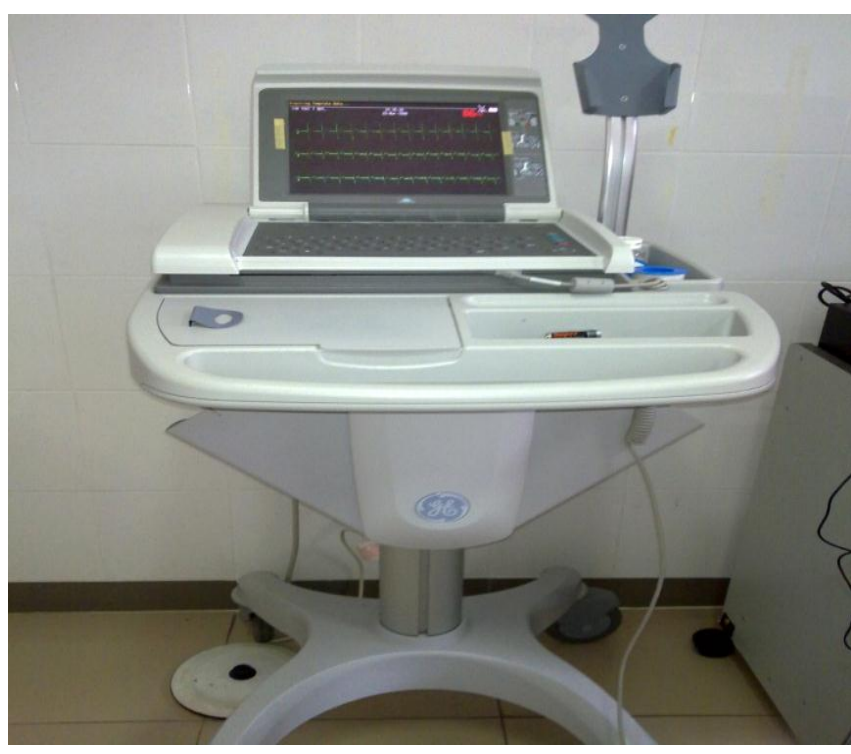

Hình 2.1. Hình ảnh máy điện tim độ phân giải cao tại BVTW Huế

Bảng 2.1. Các thông số điện thế muộn [7]

\begin{tabular}{|l|l|c|}
\hline $\begin{array}{c}\text { Thông số } \\
\text { điện thế } \\
\text { muộn }\end{array}$ & \multicolumn{1}{|c|}{ Ý nghĩa } & $\begin{array}{c}\text { Tiêu } \\
\text { chuẩn }\end{array}$ \\
\hline HFQRSd & $\begin{array}{l}\text { Thời gian phức bộ QRS } \\
\text { tần số cao được lọc }\end{array}$ & $>114 \mathrm{~ms}$ \\
\hline LAHFd & $\begin{array}{l}\text { Thời gian tín hiệu biên } \\
\text { độ thấp }<40 \mu \mathrm{V} \text { của phần } \\
\text { cuối phức bộ QRS }\end{array}$ & $>38 \mathrm{~ms}$ \\
\hline RMS40 & $\begin{array}{l}\text { Giá trị trung bình tín } \\
\text { hiệu tần số cao của } \\
40 \mathrm{msec} \text { cuối cùng phức } \\
\text { bộ QRS }\end{array}$ & $<20 \mu \mathrm{V}$ \\
\hline
\end{tabular}

Điện thế muộn dương tính khi có ít nhất 2 trong 3 tiêu chuẩn trên.

\subsubsection{Biến thiên nhịp tim/Holter 24 giò̀}

* Mắc Holter điện tim 24giờ tại phòng Holter

Phương tiện: Máy Holter điện tim SEER Light, mã số P86080028, thuộc công ty Compact Digital 
Holter của Mỹ, sản xuất tại Nhật Bản. Cáp quang tải dữ liệu từ máy ghi tới máy tính. Máy tính để bàn có khe cắm, nối máy in. Khoá hard lock key nối cùng cổng máy in có mã số. Các phương tiện trên được đặt tại phòng Holter điện tim của Trung tâm tim mạch, BVTW Huế.

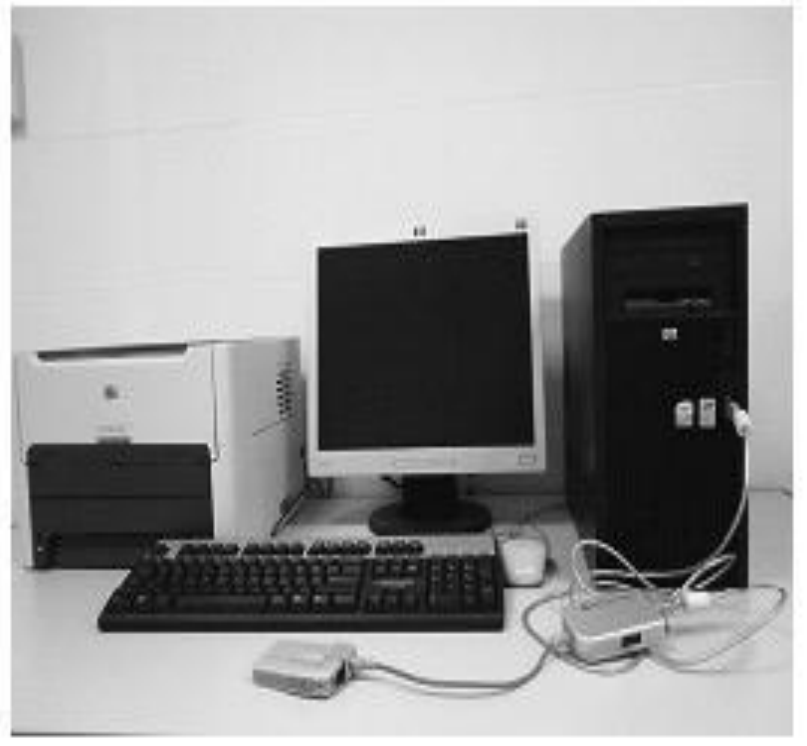

Hình 2.2. Hệ thống Holter điện tim tại BVTW Huế
Bảng 2.2. Giá trị bất thuờng các chỉ số biến thiên nhịp tim theo phổ tần số và phân tích theo thời gian [3]

\begin{tabular}{|l|c|c|}
\hline \multicolumn{1}{|c|}{ Các phổ tần số } & $\begin{array}{c}\text { Phân } \\
\text { tích theo } \\
\text { thời gian }\end{array}$ & $\begin{array}{c}\text { Giảm biến } \\
\text { thiên nhịp } \\
\text { tim/24giồ }\end{array}$ \\
\hline HF(Phổ tần số cao) & $\begin{array}{c}\text { rMSSD } \\
\text { pNN50 }\end{array}$ & $\begin{array}{c}<15 \mathrm{~ms} \\
<0,75 \%\end{array}$ \\
\hline LF (Phổ tần số thấp) & SDNNidx & $<30 \mathrm{~ms}$ \\
\hline VLF (Phổ tần số rất thấp) & SDNNidx & $<30 \mathrm{~ms}$ \\
\hline LF (Phổ tấn số cực thấp) & SDNN & $<50 \mathrm{~ms}$ \\
& SDANN & $<40 \mathrm{~ms}$ \\
\hline
\end{tabular}

Giảm biến thiên nhịp tim được ghi nhận khi có hơn một chỉ số biến thiên nhịp tim giảm xuống mức giới hạn nêu trên.

+ RLNT và tiêu chuẩn chẩn đoán:được dùng khi phân tích dữ liệu từ Holter điện tim 24 giờ theo Remipillier [1]

\subsection{Xử lý thống kê}

Chúng tôi sử dụng chương trình xử lý số liệu thống kê SPSS 16 (Statistical Package for the Social Sciences) và Medcalc 11.6.0.

\section{KẾT QUẢ NGHIÊN CÚ'U}

Qua nghiên cứu 74 bệnh nhân được chẩn đoán và đã phẫu thuật sửa chữa hoàn toàn tứ chứng Fallot, chúng tôi đã thu được các kết quả sau đây.

\section{1. Đặc điểm tuổi và giới của đối tượng nghiên cứu}

Bảng 1: Đặc điểm chung của mẫu nghiên cứu

\begin{tabular}{|c|c|c|c|c|}
\hline Chỉ số Nhóm & Nam & Nũ & Chung & p \\
\hline Giới & $41(55,41 \%)$ & $33(44,59 \%)$ & & $>0,05$ \\
\hline Tuổi (năm) & $19,68 \pm 5,54$ & $24,67 \pm 9,89$ & $21,91 \pm 8,12$ & $<\mathbf{0 , 0 5}$ \\
\hline BMI (kg/m²) & $17,26 \pm 2,10$ & $18,44 \pm 2,19$ & $17,78 \pm 2,21$ & $<\mathbf{0 , 0 5}$ \\
\hline BSA (m²) & $1,40 \pm 0,16$ & $1,36 \pm 0,10$ & $1,38 \pm 0,14$ & $>0,05$ \\
\hline Tuổi phẫu thuật & $16,68 \pm 6,87$ & $19,39 \pm 11,45$ & $17,89 \pm 9,23$ & $>0,05$ \\
\hline $\begin{array}{c}\text { Thời gian sau phẫu thuật } \\
\text { (năm) }\end{array}$ & $3,22 \pm 2,75$ & $5,45 \pm 4,25$ & $4,22 \pm 3,65$ & $<0,05$ \\
\hline
\end{tabular}

Tuổi trung bình là 21,91 $\pm 8,12$ năm.Tuổi lớn nhất là 55 tuổi.Tỷ lệ nam / nữ = 1,24. Chỉ số BMI, tuổi, thời gian sau phẫu thuật có sự khác biệt có ý nghĩa thống kê $(\mathrm{p}<0,05)$ giữa hai giới. 


\subsection{Rối loạn nhịp tim}

Bảng 2: Tỷ lệ rối loạn nhịp tim

\begin{tabular}{|l|c|c|}
\hline Dạng rối loạn nhịp tim & $\mathbf{n}$ & $\mathbf{\%}$ \\
\hline Rối loạn nhịp tim (1) & 29 & 39,19 \\
\hline Không rối loạn nhịp tim (2) & 45 & 60,81 \\
\hline Rối loạn nhịp thất & 22 & 29,73 \\
\hline Rối loạn nhịp nhĩ & 3 & 4,05 \\
\hline Bloc nhĩ thất & 8 & 10,81 \\
\hline
\end{tabular}

Có sự khác biệt có ý nghĩa thống kê giữa nhóm bệnh nhân rối loạn nhịp tim và không rối loạn nhịp tim $(\mathrm{p}<0,05)$. Tỷ lệ rối loạn nhịp thất chiếm ưu thế trong rối loạn nhịp tim ở bệnh nhân tứ chứng Fallot sau phẫu thuật so với các rối loạn nhịp khác.

Bảng 3: Rối loạn nhịp tim ở bệnh nhân có thời gian phẫu thuật trước và sau 3 năm

\begin{tabular}{|l|c|c|c|c|c|}
\hline \multirow{2}{*}{} & \multicolumn{2}{|c|}{$\leq \mathbf{3}$ năm(n=35) } & \multicolumn{2}{c|}{$>\mathbf{3}$ năm(n=39) } & \multirow{2}{*}{ p } \\
\cline { 2 - 5 } & $\mathbf{n}$ & $\mathbf{\%}$ & $\mathbf{n}$ & $\mathbf{\%}$ & \\
\hline Rối loạn nhịp tim & 13 & 37,14 & 16 & 41,03 & $>0,05$ \\
\hline Không rối loạn nhịp tim & 22 & 62,86 & 23 & 58,97 & $>0,05$ \\
\hline Rối loạn nhịp thất & 7 & 20 & 15 & 38,46 & $>0,05$ \\
\hline Rối loạn nhịp nhĩ & 2 & 5,71 & 1 & 2,56 & $>0,05$ \\
\hline Bloc nhĩ thất & 6 & 17,14 & 2 & 5,13 & $>0,05$ \\
\hline
\end{tabular}

Nhóm bệnh nhân có thời gian sau phẫu thuật lớn hơn 3 năm có tỷ lệ rối loạn nhịp tim, rối loạn nhịp thất so với nhóm bệnh nhân có thời gian sau phẫu thuật dưới 3 năm không có ý nghĩa thống kê ( $\mathrm{p}>0,05)$.

Bảng 4: Giá trị trung bình các thông số BTNT phổ thời gian theo thời gian phẫu thuật

\begin{tabular}{|c|c|c|c|}
\hline & $\mathbf{3}$ năm(n=35) & $>$ 3 năm $(\mathbf{n = 3 9})$ & p \\
\hline SDNN (ms) & $119,06 \pm 41,72$ & $125,56 \pm 40,41$ & $>0,05$ \\
\hline SDANN (ms) & $109,74 \pm 39,08$ & $111,56 \pm 38,04$ & $>0,05$ \\
\hline ASDNN (ms) & $42,63 \pm 18,03$ & $52,10 \pm 21,25$ & $<\mathbf{0 , 0 5}$ \\
\hline rMSSD (ms) & $24,33 \pm 11,57$ & $27,97 \pm 16,61$ & $>0,05$ \\
\hline pNN50 (\%) & $3,21 \pm 2,93$ & $2,95 \pm 3,04$ & $>0,05$ \\
\hline
\end{tabular}

Các thông số BTNT phổ thời gian không có sự khác biệt có ý nghĩa thống kê giữa hai nhóm bệnh có thời gian sau phẫu thuật trên dưới 3 năm $(\mathrm{p}>0,05)$ ngoại trừ thông số ASDNN giữa hai nhóm bệnh có thời gian sau phẫu thuật trên dưới 3 năm có ý nghĩa thống kê $(\mathrm{p}<0,05)$.

Bảng 5: Giá trị trung bình các thông số BTNT phổ tần số theo thời gian phẫu thuật

\begin{tabular}{|c|c|c|c|}
\hline & $\leq \mathbf{3}$ năm $(\mathbf{n}=\mathbf{3 5})$ & $>\mathbf{3}$ năm $(\mathbf{n}=\mathbf{3 9})$ & $\mathbf{p}$ \\
\hline Ln HF $\left(\mathrm{ms}^{2}\right)$ & $2,21 \pm 0,68$ & $2,22 \pm 0,62$ & $>0,05$ \\
\hline Ln LF $\left(\mathrm{ms}^{2}\right)$ & $2,49 \pm 0,64$ & $2,77 \pm 0,53$ & $<\mathbf{0 , 0 5}$ \\
\hline $\operatorname{Ln}$ VLF $\left(\mathrm{ms}^{2}\right)$ & $3,06 \pm 0,61$ & $3,32 \pm 0,41$ & $<\mathbf{0 , 0 5}$ \\
\hline Ln WF $\left(\mathrm{ms}^{2}\right)$ & $3,29 \pm 0,53$ & $3,53 \pm 0,44$ & $<\mathbf{0 , 0 5}$ \\
\hline L/H & $1,62 \pm 0,56$ & $1,81 \pm 0,49$ & $>0,05$ \\
\hline
\end{tabular}


Giá trị trung bình của các thông số LF, VLF, WF ở nhóm bệnh có thời gian sau phẫu thuật trên 3 năm lớn hơn một cách có ý nghĩa thống kê so với nhóm bệnh nhân có thời gian sau phẫu thuật dưới 3 năm (p>0,05).

Bảng 6: Giá trị trung bình các thông số BTNT phổ thời gian ở bệnh nhân rối loạn nhịp tim

\begin{tabular}{|c|c|c|c|}
\hline & RLNT (n=29) & Không RLNT (n=45) & p \\
\hline SDNN (ms) & $105,45 \pm 29,74$ & $133,47 \pm 43,54$ & $<\mathbf{0 , 0 5}$ \\
\hline SDANN (ms) & $95,69 \pm 27,01$ & $120,38 \pm 41,51$ & $<\mathbf{0 , 0 5}$ \\
\hline ASDNN (ms) & $39,17 \pm 14,94$ & $53,07 \pm 21,43$ & $<\mathbf{0 , 0 5}$ \\
\hline rMSSD (ms) & $17,62 \pm 8,31$ & $31,82 \pm 14,92$ & $<\mathbf{0 , 0 5}$ \\
\hline pNN50 (\%) & $0,54 \pm 0,47$ & $4,71 \pm 2,75$ & $<\mathbf{0 , 0 5}$ \\
\hline
\end{tabular}

Các thông số BTNT theo phổ thời gian ở bệnh nhân có rối loạn nhịp tim so với bệnh nhân không có rối loạn nhịp tim giảm có ý nghĩa thống kê $(\mathrm{p}<0,05)$.

Bảng 7: Giá trị trung bình các thông số BTNT phổ thời gian ở bệnh nhân rối loạn nhịp thất

\begin{tabular}{|c|c|c|c|}
\hline & RLNthất(n=22) & KhôngRLNthất(n=52) & p \\
\hline SDNN (ms) & $108,00 \pm 32,29$ & $128,62 \pm 42,82$ & $<\mathbf{0 , 0 5}$ \\
\hline SDANN (ms) & $98,14 \pm 29,16$ & $116,02 \pm 40,63$ & $>0,05$ \\
\hline ASDNN (ms) & $39,23 \pm 16,52$ & $51,17 \pm 20,74$ & $<\mathbf{0 , 0 5}$ \\
\hline rMSSD (ms) & $17,50 \pm 8,69$ & $30,38 \pm 14,49$ & $<\mathbf{0 , 0 5}$ \\
\hline pNN50 (\%) & $0,37 \pm 0,35$ & $4,22 \pm 2,85$ & $<\mathbf{0 , 0 5}$ \\
\hline
\end{tabular}

Các thông số BTNT theo phổ thời gian ở bệnh nhân có rối loạn nhịp thất so với bệnh nhân không có rối loạn nhịp thất giảm có ý nghĩa thống kê $(\mathrm{p}<0,05)$ ngoại trừ thông số SDANN.

Bảng 8: Giá trị trung bình các thông số BTNT phổ tần số ở bệnh nhân có rối loạn nhịp tim

\begin{tabular}{|c|c|c|c|}
\hline & RLNT $(\mathbf{n = 2 9})$ & Không RLNT $(\mathbf{n = 4 5})$ & $\mathbf{p}$ \\
\hline $\operatorname{Ln~HF}\left(\mathrm{ms}^{2}\right)$ & $1,82 \pm 0,48$ & $2,47 \pm 0,62$ & $<\mathbf{0 , 0 5}$ \\
\hline $\operatorname{Ln~LF}\left(\mathrm{ms}^{2}\right)$ & $2,46 \pm 0,51$ & $2,76 \pm 0,63$ & $<\mathbf{0 , 0 5}$ \\
\hline $\operatorname{Ln}$ VLF $\left(\mathrm{ms}^{2}\right)$ & $3,06 \pm 0,45$ & $3,28 \pm 0,56$ & $>0,05$ \\
\hline $\operatorname{Ln}$ WF $\left(\mathrm{ms}^{2}\right)$ & $3,26 \pm 0,41$ & $3,52 \pm 0,52$ & $<\mathbf{0 , 0 5}$ \\
\hline L/H & $1,98 \pm 0,54$ & $1,55 \pm 0,45$ & $<\mathbf{0 , 0 5}$ \\
\hline
\end{tabular}

Các thông số BTNT theo phổ tần số ở bệnh nhân có rối loạn nhịp tim so với bệnh nhân không có rối loạn nhịp tim giảm có ý nghĩa thống kê $(\mathrm{p}<0,05)$.

Bảng 9: Giá trị trung bình các thông số BTNT phổ tần số ở bệnh nhân có rối loạn nhịp thất

\begin{tabular}{|c|c|c|c|}
\hline & RLN thất $(\mathbf{n = 2 2})$ & Không RLN Thất $(\mathbf{n = 5 2})$ & $\mathbf{p}$ \\
\hline $\operatorname{Ln} H F\left(\mathrm{~ms}^{2}\right)$ & $1,75 \pm 0,51$ & $2,41 \pm 0,60$ & $<\mathbf{0 , 0 5}$ \\
\hline $\operatorname{Ln} \mathrm{LF}\left(\mathrm{ms}^{2}\right)$ & $2,44 \pm 0,57$ & $2,73 \pm 0,59$ & $>0,05$ \\
\hline $\operatorname{Ln}$ VLF $\left(\mathrm{ms}^{2}\right)$ & $3,05 \pm 0,54$ & $3,25 \pm 0,53$ & $>0,05$ \\
\hline $\operatorname{Ln} W F\left(\mathrm{~ms}^{2}\right)$ & $3,25 \pm 0,46$ & $3,49 \pm 0,49$ & $<\mathbf{0 , 0 5}$ \\
\hline L/H & $2,07 \pm 0,53$ & $1,57 \pm 0,46$ & $<\mathbf{0 , 0 5}$ \\
\hline
\end{tabular}


Các thông số BTNT theo phổ tần số ở bệnh nhân có rối loạn nhịp thất so với bệnh nhân không có rối loạn nhịp thất giảm có ý nghĩa thống kê $(\mathrm{p}<0,05)$.

3.3. Giá trị dự báo rối loạn nhịp tim của các phương pháp điện tâm đồ không xâm nhập

3.3.1. Điện thế muộn

Bảng 10: Dụ báo về nguy cơ rối loạn nhịp tim dụa vào điện thế muộn

\begin{tabular}{|c|c|c|c|}
\hline & Rối loạn nhịp tim (n) & Không rối loạn nhịp tim (n) & OR \\
\hline Điện thế muộn dương tính & 16 & 11 & OR=3,80, p<0,05, \\
\hline Điện thế muộn âm tính & 13 & 34 & $95 \% \mathrm{CI}=1,40-10,33$ \\
\hline
\end{tabular}

Qua bảng trên ta thấy nếu bệnh nhân có ĐTM(+) thì dự báo khả năng rối loạn nhịp tim lớn gấp 3,80 lần $(\mathrm{OR}=3,80 ; \mathrm{p}<0,05)$ so với nhóm có ĐTM(-). ĐTM dự báo rối loạn nhịp tim với độ nhạy 55,17 (95\%CI:35,6973,55), độ đặc hiệu 75,56\%(95\%CI:60,46-87,12).

Bảng 11: Dụ báo về nguy cơ rối loạn nhịp thất dụa vào điện thế muộn

\begin{tabular}{|c|c|c|c|}
\hline & Rối loạn nhịp thất (n) & Không rối loạn nhịp thất (n) & OR \\
\hline Điện thế muộn dương tính & 12 & 15 & \multirow{2}{*}{ OR=2,96, p<0,05, } \\
Điện thế muộn âm tính & 10 & 37 & $\mathrm{CI}=1,06-8,30$ \\
\hline
\end{tabular}

Qua bảng trên ta thấy nếu bệnh nhân có $\mathrm{ĐTM}(+)$ thì dự báo khả năng rối loạn nhịp thất lớn gấp 2,96 lần $(\mathrm{OR}=2,96 ; \mathrm{p}<0,05)$ so với nhóm có ĐTM(-). ĐTM dự báo rối loạn nhịp thất với độ nhạy 54,55 (95\%CI:32,2175,61), độ đặc hiệu 71,15\%(95\%CI:56,92-82,87).

Độ nhạy

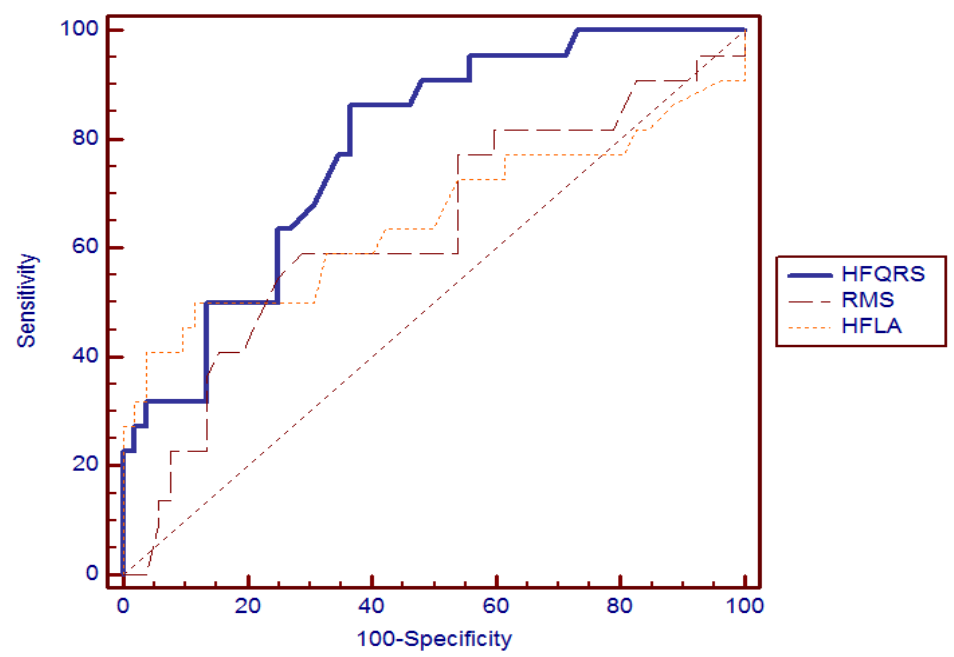

Độ đặc hiệu

Biểu đồ 1: Đường cong ROC các thông số điện thế muộn trong tiên lượng rối loạn nhịp thất

Điểm cắt tốt nhất của HFQRSd trong tiên lượng rối loạn nhịp thất là lớn hơn $151 \mathrm{~ms} ; \mathrm{AUC}=0,783$ (95\% CI: 0,67-0,87); Độ nhạy: 86,4\% (95\%CI: 65,1-97,1); Độ đặc hiệu: 63,5\% (95\%CI: 49 - 76,4). Điểm cắt tốt nhất của HFLA trong tiên lượng rối loạn nhịp thất là lớn hơn $47 \mathrm{~ms}$; AUC=0,654 (95\% CI: 0,53-0,76); Độ nhạy: 50\% (95\%CI: 28,2-71,8); Độ đặc hiệu: 88,5\% (95\%CI: 76,6 - 95,6). Điểm cắt tốt nhất của RMS trong tiên lượng rối loạn nhịp thất là nhỏ hơn hoặc bằng $21 \mu \mathrm{V}$; $\mathrm{AUC}=0,633$ (95\% CI: 0,51-0,74); Độ nhạy: 59,1\% (95\%CI: 36,4-79,3); Độ đặc hiệu: 71,2 \% (95\%CI: 56,9 - 82,9). 


\subsubsection{Biến thiên nhịp tim / Holter điện tim 24 giờ}

Bảng 12: Dụ báo về nguy cơ rối loạn nhịp tim của biến thiên nhịp tim

\begin{tabular}{|c|c|c|c|}
\hline & $\begin{array}{c}\text { Rối loạn nhịp } \\
\text { tim (n) }\end{array}$ & $\begin{array}{c}\text { Không rối loạn } \\
\text { nhịp tim (n) }\end{array}$ & OR \\
\hline Giảm BTNT & 18 & 6 & \multirow{2}{*}{ OR=10,64, p<0,05, } \\
Không giảm BTNT & 11 & 39 & CI=3,39-33,28 \\
\hline
\end{tabular}

Bệnh nhân có BTNT giảm thì dự báo khả năng rối loạn nhịp tim lớn hơn gấp 10,64 lần $(\mathrm{OR}=10,64$; $\mathrm{p}<0,05)$ so với nhóm không giảm BTNT. BTNT dự báo rối loạn nhịp tim với độ nhạy $62,07 \%$ (95\% CI: 42,2679,31), độ đặc hiệu 86,67\% (95\%CI:73,21-94,95).

Bảng 13: Dụ báo về nguy cơ rối loạn nhịp thất của biến thiên nhịp tim

\begin{tabular}{|c|c|c|c|}
\hline & $\begin{array}{c}\text { Rối loạ́n nhịp } \\
\text { thất (n) }\end{array}$ & $\begin{array}{c}\text { Không rối loạn } \\
\text { nhịp thất (n) }\end{array}$ & OR \\
\hline Giảm BTNT & 16 & 8 & \multirow{2}{*}{$\begin{array}{c}\text { OR=14,67, p<0,05, } \\
95 \% \mathrm{CI}=4,40-48,85\end{array}$} \\
\hline Không giảm BTNT & 6 & 44 & \\
\hline
\end{tabular}

Bệnh nhân có BTNT giảm thì dự báo khả năng rối loạn nhịp thất lớn hơn gấp 14,67 lần $(\mathrm{OR}=14,67$; $\mathrm{p}<0,05)$ so với nhóm không giảm BTNT. BTNT dự báo RLNThất với độ nhạy 72,73\% (95\%CI:49,78-89,27), độ đặc hiệu 84,62\% (95\%CI:71,92-93,12).

\subsubsection{Giá trị phối họ̣p các phương pháp điện tim dụ̣ báo rối loạn nhịp tim}

Bảng 14: Dụ báo nguy cơ rối loạn nhịp tim dụa vào điện thế muộn và biến thiên nhịp tim/Holter điện tim 24 giò̀

\begin{tabular}{|l|c|c|c|c|c|c|}
\hline & OR & $\mathbf{p}$ & $\begin{array}{c}\text { Độ nhạy } \\
(\mathbf{\%})\end{array}$ & $\begin{array}{c}\text { Độ đặc hiệu } \\
(\mathbf{\%})\end{array}$ & $\begin{array}{c}\text { PPV } \\
(\mathbf{\%})\end{array}$ & $\begin{array}{c}\text { NPV } \\
(\boldsymbol{\%})\end{array}$ \\
\hline BTNT(+) và ĐTM(+) & 13,14 & $<\mathbf{0 , 0 5}$ & 37,93 & 95,96 & 84,62 & 70,49 \\
\hline BTNT(-) và ĐTM(+) & 0,92 & $>0,05$ & 17,24 & 80 & 35,71 & 60 \\
\hline BTNT(+) và ĐTM(-) & 3,26 & $>0,05$ & 24,14 & 91,11 & 63,64 & 65,08 \\
\hline ĐTM(-) và BTNT(-) & 0,13 & $>0,05$ & 20,69 & 33,33 & 16,67 & 39,47 \\
\hline
\end{tabular}

Bệnh nhân có $\mathrm{ĐTM}(+)$ và giảm $\mathrm{BTNT}$ thì dự báo khả năng rối loạn nhịp tim cao gấp 13,14 lần $(\mathrm{OR}=13,14)$ so với nhóm bệnh nhân có $\mathrm{ÐTM}(-)$ và $\mathrm{BTNT}$ không giảm, với $\mathrm{p}<0,05$.

\section{BÀN LUẬN}

\section{1. Đặc điểm chung của nhóm nghiên cứu}

Về giới tính, trong nghiên cứu của chúng tôi có 41 nam và 33 nữ, tỷ lệ là $55,41 \%$ và $44,59 \%(\mathrm{p}>0,05)$ theo bảng 3.1. Theo nghiên cứu của Lê Quang Thứu có 82 nam và 55 nữ, tỷ lệ là $59,85 \%$ và $40,15 \%$ [1]. Kết quả nghiên cứu của Luijnenburg $\mathrm{SE}$ và các cộng sự, nam chiếm $62 \%$ và nữ $38 \%$ [12]. Trong nghiên cứu của Valente và cộng sự, tỷ lệ nam là $55 \%$ nữ là $45 \%$ [16]. Tỷ lệ nam là 53\% theo nghiên cứu của Kipps AK [11]. Kết quả của chúng tôi khá tương đồng so với các kết quả của các tác giả.Độ tuổi nghiên cứu của chúng tôi là $21,91 \pm 8,12$ năm, có sự khác biệt có nghĩa thống kê giữa độ tuổi nam và nữ $(p<0,05)$. Với nghiên cứu của tác giả Budts $\mathrm{W}$ và cộng sự, tuổi nghiên cứu trung bình là 24 năm [5]. Nghiên cứu của tác giả Brili $\mathrm{S}$ và cộng sự, tuổi nghiên cứu trung bình là 27,3 $\pm 11,7$ năm [4]. Qua nghiên cứu của Valente, tuổi nghiên cứu trung bình là 24,4 năm và 18,7 năm là độ tuổi trung bình trong nghiên cứu của Vogel M [18]. Theo nghiên cứu của Zeng DW, tuổi nghiên cứu trung bình là $29,5 \pm 10,65$ [22] và nghiên cứu của $\mathrm{Yu} \mathrm{HK}$, tuổi nghiên cứu trung bình 24,76 \pm 8,6 năm [21]. 


\section{2. Điện thế muộn}

Phát hiện sớm cácrối loạn nhịp timsau phẫu thuậtbệnh tim bẩm sinhrất quan trọng vìnó có thể giúp giảm tỷ lệ mắc bệnh và tử vong.Sử dụng điện tim có độ phân giải cao, biên độcao nhất của các thành phầntần số cao trong phức bộ QRS có thể được ghi lại và phân tích nhằm phát hiện các nguy cơ rối loạn nhịp tim, nhịp thất [13].

Bệnh nhân tứ chứng Fallot:bloc nhánh phải sẽ dẫn đến sự dẫn truyền không đồng nhất thường xuất hiện muộn, do đó sự dẫn truyền này chỉ có thể được nhìn thấy ở phần cuối của phức bộ và dẫn đến điện thế RMS thấp hơn so với nơi bắt đầu của bloc nhánh phải. Nhiều nghiên cứu cho rằng chính các tổn thương dây thần kinh tim trong quá trình phẫu thuật đã tạo tiền đề cho các cơn nhịp nhanh thất có vòng vào lại [15]. Một sự hiện diện bất thường của mô xơ tại cácvị trí khác nhau của tâm thất phải ở những bệnh nhân đã trải qua phẫu thuật sửa chữa cho tứ chứng Fallot đặc biệt là những bệnh nhântrải qua phẫu thuật muộn (sau $5-8$ năm). Những khu vực tổn thương cơ tim có thể cung cấp chất nền cho những bất thường khử cực tâm thất.Những bất thườngtại chỗ xuất hiện có liên quan đến rối loạn nhịp thất nghiêm trọng[8].

Qua nghiên cứu, chúng tôi nhận thấy: Giá trị các thông số ĐTM (HFQRSd, HFLA) ở nhóm rối loạn nhịp tim, rối loạn nhịp thất lớn hơn nhóm không rối loạn nhịp tim, rối loạn nhịp thất có ý nghĩa thống kê. Có sự khác biệt có ý nghĩa thống kê thông số HFQRSd giữa 2 nhóm phẫu thuật cũng như giữa hai nhóm bệnh có thời gian sau phẫu thuật trên dưới 3 năm $(\mathrm{p}<0,05)$.

\subsection{Biến thiên nhịp tim}

Rối loạn nhịp tim và đột tử đã được chứng minh có liên quan đến sự thay đổi của hệ thống thần kinh tự độngtrongcác bệnh tim mạch khác nhau. Giảm biến thiên nhịp tim ở bệnh nhân tứ chứng Fallot có rối loạn nhịp tim do sự thay đổi huyết động thất phải [20]. Biến thiên nhịp tim phân tích được sử dụng rộng rãi trongcác bệnh tim mạch người lớn để đánh giá chức năng hệ thần kinh[6].Giảm biến thiên nhịp tim xuất hiện ở bệnh nhân sửa chữa tứ chứng của Fallot, và liên quan với độ rộng của phức bộ QRS. Việc giảm biến thiên nhịp tim tương ứng với giãn thất phải và áp lực thất phải, nhưng không liên quan với chức năng thất phải.Có một số bằng chứng cho thấy hở van động mạch phổi có liên quan rõ ràng với giảm biến thiên nhịp tim. Chính vì vậy, giảm biến thiên nhịp tim là một yếu tố dự báo độc lập hữu ích cho rối loạn nhịp thất và đột tử muộn [14].

Nếu bệnh nhân có biến thiên nhịp tim giảm thì dự báo khả năng rối loạn nhịp tim lớn hơn gấp 10,64 lần $(\mathrm{OR}=10,64$ khoảng tin cậy $95 \% \quad(3,39$ $33,28), p<0,05)$ so với nhóm không giảm biến thiên nhịp tim. Nếu bệnh nhân có biến thiên nhịp tim giảm thì dự báo khả năng rối loạn nhịp thất lớn hơn gấp 14,67 lần $(\mathrm{OR}=14,67$ khoảng tin cậy $95 \%$ $(4,40-48,85), \mathrm{p}<0,05)$ so với nhóm không giảm biến thiên nhịp tim.

Như vậy, bệnh nhân tứ chứng Fallot sau khi phẫu thuật sửa chữa hoàn toàn, có một tỷ lệ đáng kể của rối loạn nhịp thất nghiêm trọng [51]. Phân tích biến thiên nhịp tim/Holter điện tim 24 giờ là một phương pháp hữu íchđể xác định bệnh nhân loạn nhịp tim,và thông số $\mathrm{SDNN}$ dường như là chỉ số hữu ích.Theo tác giả Butera $\mathrm{G}$, thông số pNN50 là một yếu tố dự báo độc lập rối loạn nhịp thất [6].

\subsection{Kết hợp các phương pháp điện tim trong dự báo rối loạn nhịp tim}

Trong nghiên cứu của tác giả Khairy và cộng sự (2010), tỷ lệ rối loạn nhịp thất chiếm tỷ lệ $14,6 \%$ và tỷ lệ cần đặt máy phá rung (ICD) là $10,4 \%$ đối với bệnh nhân tứ chứng Fallot sau phẫu thuật sửa chữa hoàn toàn $[10]$.

Khi kết hợp hai phương pháp điện tim không xâm nhập thì sự kết hợp giữa hai phương pháp biến thiên nhịp tim và điện thế muộn cho kết quả dự báo tốt nhất với khả năng dự báo rối loạn nhịp tim với OR là 13,14; p<0,05; độ nhạy: 37,93\%; độ đặc hiệu: 95,96\%; giá trị dự báo dương tính: $84,62 \%$; giá trị dự báo âm tính: 70,49\% so với dùng phương pháp biên thiên nhịp tim hay điện thế muộn đơn độc.

\section{TÀI LIỆU THAM KHẢO}

\section{Tiếng Việt}

1. Hoàng Anh Tiến. (2010), Nghiên cưu vai trò NT-proBNP huyết tuoong và đánh giá luân phiên sóng T điện tâm đồ trong tiên lương bệnh nhân suy tim, Luận án tiến sĩ Y học, Trường Đại Học Y Dược Huế.

2. Hội Tim mạch học Việt Nam (2010), Khuyến cáo 2010 của hộ tim mạch học Việt Nam về xủ lý bệnh tim bẩm sinh ở người lớn, in Khuyến cáo 2010 
về các bệnh lý tim mạch và chuyển hóa $\mathrm{Nxb} \mathrm{Y}$ học. tr. 7-76.

3. Huỳnh Văn Minh. (2009), Biến thiên nhịp tim, in Holter điện tâm đồ 24 giờ trong bệnh lý tim machNxb Đại học Huế. tr. 130-170.

\section{Tiếng Anh}

4. Brili S Aggeli C, Gatzoulis K, (2001), Echocardiographic and signal averaged ECG indices associated with non-sustained ventricular tachycardia after repair of tetralogy of fallot, Heart, 85(1), tr. 57-60.

5. Budts W Defoor J, Stevens A , (2005), Changes in QRS duration are associated with maximal exercise capacity in adult patients with repaired tetralogy of Fallot, Int J Cardiol, 104(1), tr. 46-51.

6. Butera G Bonnet D, Sidi D et al., (2004), Patients operated for tetralogy of fallot and with nonsustained ventricular tachycardia have reduced heart rate variability, Herz, 29(3), tr. 304-309.

7. Cain ME Anderson JL, Arnsdorf MF et al. (1996), Signal-Averaged Electrocardiography, JACC, 27(1), tr. 238 - 249.

8. Daliento L Caneve F, Turrini P, Buja G., (1995), Clinical significance of high-frequency, lowamplitude electrocardiographic signals and $Q T$ dispersion in patients operated on for tetralogy of Fallot”, Am J Cardiol, 76(5), tr. 408-411.

9. Folino AF Daliento L. (2005), Arrhythmias after tetralogy of fallot repair, Indian Pacing Electrophysiol J,, 5(4), tr. 312-324.

10. Khairy P Aboulhosn J, Gurvitz MZ, (2010), Arrhythmia burden in adults with surgically repaired tetralogy of Fallot: a multi-institutional study, Circulation, 122(9), tr. 868-875.

11. Kipps AK Graham DA, Harrild DM., (2011), Longitudinal exercise capacity of patients with repaired tetralogy of fallot, Am J Cardiol, 108(1), tr. 99-105.

12. Luijnenburg SE Helbing WA, Moelker A et al. (2013), 5-year serial follow-up of clinical condition and ventricular function in patients after repair of tetralogy of Fallot, Int J Cardiol, 169(6), tr. 439-444.

13. Omeroglu RE Olgar S, Nisli K. (2007), Signal-averaged electrocardiogram may be a beneficial prognostic procedure in the postoperative follow-up tetralogy of fallot patients to determine the risk of ventricular arrhythmias, Pediatr Cardiol, 28(3), tr. 208-212.

14. Steeds RP Oakley D. (2004), Predicting late sudden death from ventricular arrhythmia in adults following surgical repair of tetralogy of Fallot, QJM, 97(1), tr. 7-13.

15. Vaksmann G el Kohen M, Lacroix D, (1993), Influence of clinical and hemodynamic characteristics on signal-averaged electrocardiogram in postoperative tetralogy of Fallot, Am J Cardiol, 71(4), tr. 317-321.

16. Valente AM Gauvreau K, Assenza GE., (2014), Contemporary predictors of death and sustained ventricular tachycardia in patients with repaired tetralogy of Fallot enrolled in the INDICATOR cohort, Heart, 100(3), tr. 247-253.

17. Villafañe J Feinstein JA, Jenkins KJ, (2013), Hot topics in tetralogy of Fallot, J Am Coll Cardiol, 62(23), tr. 2155-2166.

18. Vogel M Sponring J, Cullen S et al. (2001), Regional wall motion and abnormalities of electrical depolarization and repolarization in patients after surgical repair of tetralogy of Fallot, Circulation, 103(12), tr. 1669-1673.

19. Warnes CA Williams RG, Bashore TM, (2008), ACC/AHA 2008 Guidelines for the Management of Adults with Congenital Heart Disease: Executive Summary: a report of the American College of Cardiology/American Heart Association Task Force on Practice Guidelines, Circulation, 118(23), tr. 2395-2451.

20. Wyller VB Saul JP, Barbieri R et al., (2008), Autonomic heart rate control at rest and during unloading of the right ventricle in repaired tetralogy of Fallot in adolescents, Am J Cardiol, 102(8), tr. 1085-1089.

21. Yu HK Li SJ, Ip JJ et al. (2014), Right ventricular mechanics in adults after surgical repair of tetralogy of fallot: insights from three-dimensional speckle-tracking echocardiography, J Am Soc Echocardiogr, 27(4), tr. 423-429.

22. Zheng DW Shao GF, Feng Q, Ni YM., (2013), Long-term outcome of correction of tetralogy of Fallot in 56 adult patients, Chin Med J (Engl), 126(19), tr. 3675-3679. 